\title{
Biodiversity and Indigenous Use of Medicinal Ferns in Chandraprabha Wildlife Sanctuary, Chandauli, Uttar Pradesh
}

\author{
Shashank Kumar Singh, S. Dominic Rajkumar \\ Department of Botany, St. Andrew's College (PG), Gorakhpur, UP \\ *Corresponding Author: Shashank Kumar Singh, Department of Botany, St. Andrew's College (PG), \\ Gorakhpur, UP
}

\begin{abstract}
The present study highlights the traditional knowledge of tribe related with the use of pteridophytic plants as ethno medicine. Extensive field trips were conducted in order to collect the ethnobotanical information of Chandraprabha wild life sancuatary. Questionnaire was made to gather data for local name, part used, disease treated, mode of administration and methods of preparation. The present article gives a brief account of 16 plants species belonging to 11 families used as herbal remedies by local tribes of Chandauli.
\end{abstract}

Keywords: Ethnomedicinal, Pteridophytes, Chandraprabha wild life sancuatary, Chandauli, Uttar Pradesh.

\section{INTRODUCTION}

India is rich in its tribal population from the ancient time with traditional knowledge system which deals with various important aspects and the health issues of the tribals. The folk people get their treatment with the help of local practitioners and own herbal preparations. The use of herbal medicines by the tribal communities is influenced by distinct socio-cultural practices, beliefs, support of traditional authority and services of traditional medicine men. These people have a close relationship with their ambient environment and basically depend on it for primary healthcare as they live in remote localities far away from modern facilities. Tribal people are the ecosystem people who live in close harmony with the nature and maintain a close relationship between man and environment and indigenous cultures are closely maintained by the tribal and other forest dwellers throughout the world.

The economic importance of Pteridophytes is well known. Theophrastus (327-287 BC) and Discorides (50 AD) had referred the medicinal attributes of certain ferns. The ferns had an important role in folk fore. These plants have been successfully used in the Ayurvedic, Unani, Homeopathic and other systems of medicines as well as in the human history. Pteridophytes are used by the physicians in Unani system of medicine (Uddin et al., 1998). In Chinese system of medicine, many Pteridophytes are prescribed by local doctors (Kimura and Noro, 1965). Later on modern biological and pharmaceutical studies were carried out on pteridophytes by different workers. Dixit and Vohra (1984) reported edible and medicinally important pteridophytic species from India. Kaushik (1998) emphasized on the ethnobotanical importance of ferns from Rajasthan state of India. The ethnobotanical uses of this unique group are of immense importance (Singh et al., 1989, \& Dhiman, 1998). The most important studies on food and medicinal values of pteridophytes were conducted by Nayar (1957), Hodge (1973), and Dixit (1974, 1975). Recently, Ghosh et al., (2004) reported some edible pteridophytes as vegetables and medicines. Different parts are used as a medicinal value like rhizome, stem, fronds, pinnae and spores for treatment of various diseases. Many numbers of publications are seen in different fields like taxonomy, ecology and cytology of pteridophytes but only a hand full of reports are available regarding the medicinal properties and uses. A comprehensive list of Indian pteridophytes has been prepared by Dixit, (1984) and Chandra (2000). The ecological studies on the fens of Palni hills have been worked by Manickam and Ninan (1984). The present study has been made to explore the Ethnomedicinal uses of Pteridophytes. Pteridophytes are used in different medicinal field like Ayurveda and Unani. Some pteridophytes are used in Homeopathic industry. 


\section{STUDY AREA}

The study area Chandraprabha wild life sancuatary is located in the northern state of Uttar Pradesh. Chandraprabha sanctuary covers an area of $78 \mathrm{sq} \mathrm{km}$ and is situated on Vijaigarh and Naugarh hillocks in the Vindhya forest range in Chandauli. The sanctuary is adorned with lush and dense natural vegetation, spectacular waterfalls, such as, Devdari and Rajdari and endowed with stunning picnic spots that attracts numerous visitors to the region. Chandraprabha sanctuary, established in the year 1957, is located almost $70 \mathrm{~km}$ from Varanasi. Asiatic Lions were introduced at the sanctuary in the year 1958. The sanctuary is with a variety of flora and fauna and is popular amongst tourists throughout the country.

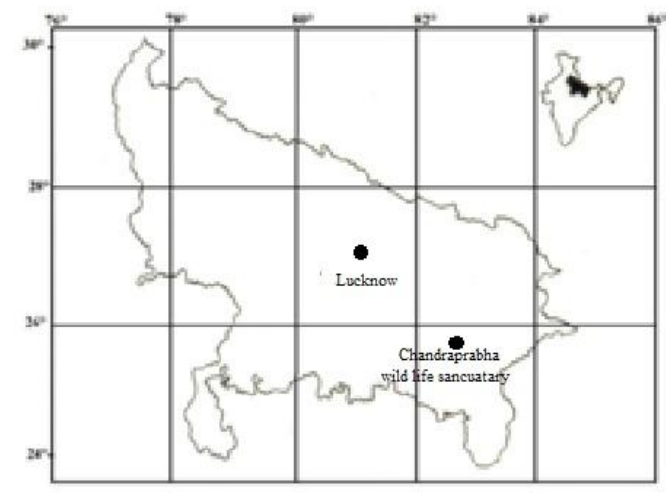

Fig1. Map of study Area

\section{MATERials AND MethodS}

Survey and collection of pteridophytes from Chandraprabha wild life Sanctuary of Chandauli district in Uttar Pradesh were made. Samples of each species were collected to prepare herbarium. Information about common name, uses of plants and their parts by local tribes for various purposes were gathered. Interviews with the tribes, herbalists, forest guards, watchers, medicine men, witchmen (ojha) and common men were conducted to retrieve information about sustainable utilization of pteridophytes. Knowledge about process of preparation of decoction and application for useful purposes was also gathered. In total 16 species were found to be potentially utilized by the local tribes for different purposes. Information about common name, ailments, medicinal uses, methods of preparation of pastes and dosage of cure were also recorded. A detailed account on sustainable utilization and useful aspects of pteridophytes in the livelihood of local tribes are provided below.

\section{RESUlts}

The present data is outcome of fieldwork carried out in Chandraprabha wild life sancuatary, Chandauli district Uttar Pradesh between 2014 to 2016. All the specimens were collected in duplicate and they are deposited in Centre for plant species biology (CPSB), St. Andrew's college, Gorakhpur, Uttar Pradesh India. About 16 species of Pteridophytes with medicinal properties have been collected from the wild life sancuatary. Their botanical name, local name, family, mode of use and parts used are given below.

\subsection{Adiantum philippense L. (Adiantaceae)}

Common name: Hanswati, Kaante Jhar, Kali Sundhiya.

Ethnomedicinal Uses: Stipe and rachis are used as ear ornament (studs). Paste of the plant mixed with mustard oil is used as ointment for cure of the boils. A fresh leaf is used for cure of fits (Khare \& Kumar 2007). Rhizome used for anti-fertility, fronds used as a decoction for the pulmonary infections. Rhizome is used for treating dysentery and glandular swelling (Sen \& Ghosh 2011). Leaf paste is used in treatment of leprosy and hair fall. It is used to remove obsession. Rhizome is administered to women for sterility. Whole plant is crushed and applied around navel region in flatulence. Fresh leaf $(2 \mathrm{gm})$ paste is taken orally on empty stomach twice a day for ten days for relief from indigestion (Rout et al. 2009, Singh \& Khare 2011). 


\subsection{Adiantum incisum Forrsk. (Adiantaceae)}

Common name: Mayurshikha, sumble, hansraj, raja hans.

Ethnomedicinal Uses: The leaves are used as a cure for cough, fever and chest affection. They are also employed for diabetes and externally the leaf paste is used to cure skin diseases. It has antibacterial properties also.

\subsection{Adiantum capillus-veneris L. (Adiantaceae)}

Common name: Hansraj, Hanspadi, Samalpatti, Pursha, Dumtuli

Ethnomedicinal Uses: Promotes growth of hairs (hence called Maiden Hair Fern), used as astringent, purgative, tonic and diuretic, effective in small pox, extracts of fronds are effective in bronchial infections, cough and cold, throat pain, fever and menstrual irregularities. Decoction of leaves is used in bronchial congestions. Extract along with honey is effective in eye ailments. Fronds are also used for its magico-religious values.

\subsection{Cheilanthes tenuifolia Swartz. (Sinopteridaceae)}

Common name: Narrow-leaved lip Fern, Resam Lumut.

Ethnomedicinal Uses: Roots are prescribed for sickness attributed to witchcraft or the avil eye. Leaves are used as a poultice on swollen limbs. Tribals use the extract of rhizome and roots as a general tonic.

\subsection{Cheilanthes bicolor (Roxb.in Griff.) Griff. ex Fras.-Jenk., (Sinopteridaceae)}

Common name: Kali sanka, silver fern

Ethnomedicinal Uses: Plant powder is mixed with cow's ghee and used as an incense to keep off fear in children. Brown stipes is used by the children as nose and ear studs. Root used in sickness.

\subsection{Ophioglossum peteolatum Hook. (Ophioglossaceae)}

Common name: Shaambli, Ekpatiya, jibiya, jibhi

Ethnomedicinal Uses: Ophioglossum peteolatum is an appreciated vegetable, collected sedulously wherever it is common. It is eaten fresh as salad, or cooked, alone or mixed with other vegetables. The leaves should be cooked gently; otherwise they turn completely into slime. In India the leaves are used as a substitute for spinach and it is used as a herbal medicine which is anti-inflammatory and anti-swelling. Leaves boiled in oil are a remedy for wounds. Thick paste of fresh rhizomes and tubers is effective in hair fall.

\subsection{Ophioglossum costatum R. Br. (Ophioglossaceae)}

Common name: Shaambli, Ekpatiya, jibiya, jibhi

Ethnomedicinal Uses: Used as a cooling agent and in the treatment of inflammations and wounds. Fronds are used as tonic and styptic. Dried tubers are powdered and used in the case of skin disease.

\subsection{Selaginella bryopteris L. (Selaginellaceae)}

Common name: Sanjeevani, Devbooti

Ethnomedicinal Uses: Plant is used as diuretic and in gonerrhoea. The dried plants along with tobacco are smoked by tribal people for inducing hallucinations in witch craft and worship Antifungal effect of amentoflavone derived from Selaginella tamariscina has paved way to the scientists to explore this antimicrobial property in Selaginella bryopteris also. Selaginella bryopteris is considered as anti-inflammatory and cures venereal disease and its usage is also known to local indigenous people, such as Songhati people. Selaginella bryopteris is a highly drought and stress resistant plant. This resistance comes from its exquisite heat-shock proteins. The aqueous extract of S. bryopteris protects cells against oxidative stress induced cell death. Cells in which growth was suppressed by $50 \%$ by thermal radiation showed reversal of suppression when they had been pre-treated with 1-10\% of the herbal extract of Selaginella for $1 \mathrm{~h}$. It is used in treating jaundice and is given to pregnant women for easy delivery. 


\subsection{Azolla pinnata R. Br. (Azollaceae)}

Common name: mosquito fern

Ethnomedicinal Uses: Azolla pinnata has become important as an organic fertilizer in tropical lowland rice production in South-East Asia. It can be grown in dual culture with wet rice or as a cover crop grown during the cultivation of rice and incorporated into the soil as a green manure. It maintains a symbiotic association with the blue-green alga Anabaena azollae Strasb. ex Wittr., Nordst. \& Lagerh. which is able to fix atmospheric nitrogen. Other crops where A. pinnata is applied as much or as green manure include taro (Colocasia esculenta (L.) Schott), Manchurian wild rice (Zizania latifolia (Griseb.) Turcz. ex Stapf) and arrowhead ( Sagittaria trifolia L.). Commercial production of Azolla compost has been realized. A dense cover of A. pinnata on water has been found to be quite effective as a means of mosquito control by the local tribal people. Waste material of A. pinnata is used as a substrate for cultivating edible mushrooms, e.g. Pleurotus sp.

\subsection{Marsilea minuta L. (Marsileaceae)}

Common name: Chilchilejhar

Ethnomedicinal Uses: The extract of whole plants is used by the local tribes as aphrodisiac and for increased fertility. The leaves are pounded, cooked with rice and then eaten as a treatment for indigestion the leaf juice is used to stop nose bleeding. The leaves are rolled in a leaf of Shorea robusta, the whole is then boiled and then applied to swollen gums in order to reduce the swelling. The leaf extract is also known to reduce cholesterol and triglyceride levels in blood and liver substantially.

\subsection{Salvinia natans L. (Salviniaceae)}

Common name: Water moss

Ethnomedicinal Uses: The plant use as an antifungal agent

\subsection{Helminthostachys zeylanica L. Hook. (Ophioglossaceae)}

Common name: Kamraj, Majurkutti, Majurpair, Bankand, Jhotphokri

Ethnomedicinal Uses: Leaves are aperients, intoxicant, anodyne and used to relieve sciatica. Rhizomes used to cure dysentery, catarrh, malaria, as an antidote for snake poison and as a tonic. Decoction of the rhizome is used to treat impotency. Leaf juice reportedly relieved blisters on the tongue. Strobilus of the plant is used as vegetable. Extract of rhizome and entire plant is used as aphrodite. Rhizome mixed with other plants is used as tonic for the cure of waist pain.

\subsection{Ceratopteris thalictroides (L) Brongn. (Parkeriaceae)}

\section{Common name:}

Ethnomedicinal Uses: The uncurled fronds are eaten as a salad or as a substitute for asparagus. Plants are used as a green manure in rice fields. The tribal people use the plant as a poultice for skin problems. It is also used as an ornamental plant in fish aquarium.

\subsection{Diplazium esculentum (Retz.) Sw. (Athyriaceae)}

Common name: Kochiya, Lukda, Dheki, Pani-neure.

Ethnomedicinal Uses: New fronds are used as vegetable. Entire plant is used as fodder for cow and goat. Crozier or tender leaf is used as salad and pickles (Sen \& Ghosh 2011). Young and fresh frond is boiled with salt and taken for maintain all-round health (Shil \& Choudhury 2009). Rhizome is used as insect inhibiter in seed storage. Decoction of rhizome along with $2 \mathrm{ml}$ of honey is taken in empty stomach to cure spermatorrhoea (Rout et al. 2009, Singh \& Khare 2011).

\subsection{Thelypteris dentata (Forssk.) (Thelypteridaceae)}

Common name: Macchi-neure, Limra.

Ethnomedicinal Uses: Thelypteris dentata has been found to be an herbal medicine, as it has antibacterial properties from the alcoholic and chloroform extracts. Juvenile fronds used as vegetable, however entire plant is used as fodder. 
Biodiversity and Indigenous Use of Medicinal Ferns in Chandraprabha Wildlife Sanctuary, Chandauli, Uttar Pradesh

\subsection{Pteris vittata L. (Pteridaceae)}

Common name: Brake fern

Ethnomedicinal Uses: Leaves used in worship at the time of illness. Fronds are largely used as cushion for cattle sheds. Leaf juice reportedly relieved blisters on the tongue.

\section{DISCUSSION}

The Pteridophytes are widely used by the local people of the tribes of Chandauli for ethnomedicinal purpose. The present article gives a brief account of 16 plants species belonging to 11 families used as herbal remedies by local tribes of Chandauli.

\section{ACKNOWLEDGEMENT}

The authors are thankful to the Principal, St. Andrew's college (PG), Gorakhpur, Uttar Pradesh for the facilities and the encouragement given to us.

\section{PLATE - 1}
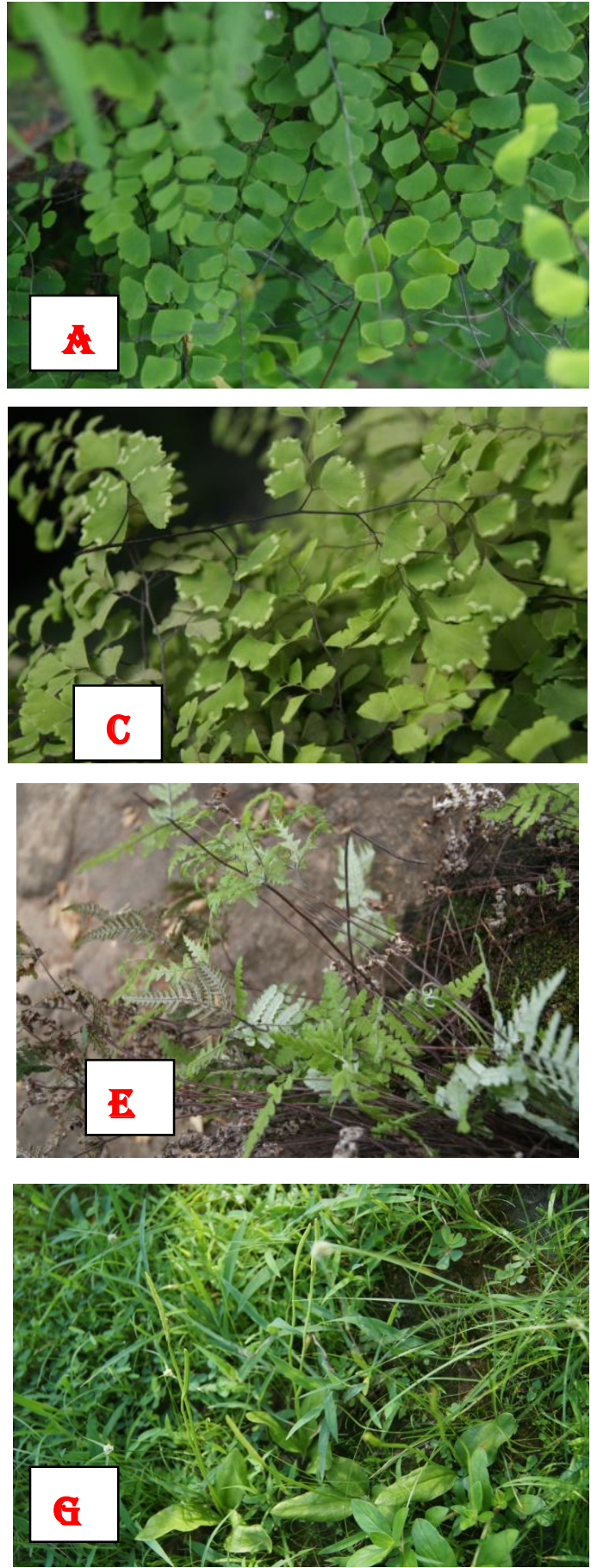
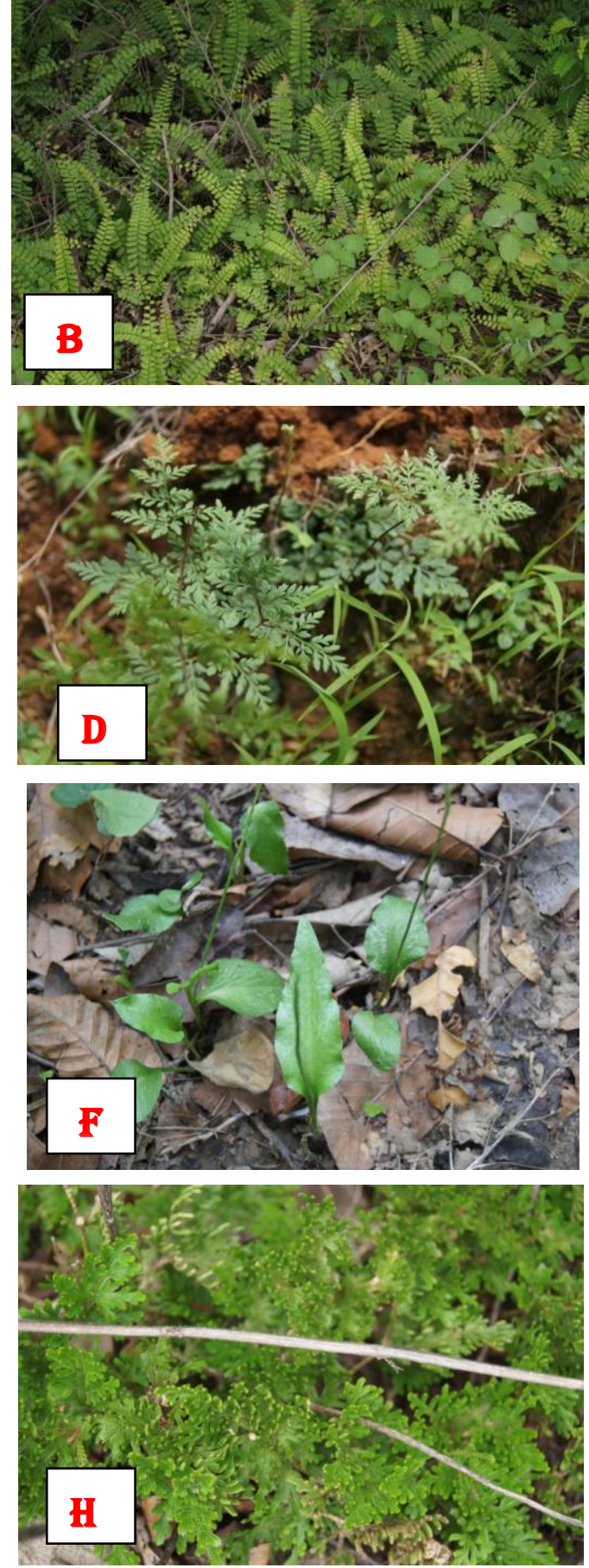
Biodiversity and Indigenous Use of Medicinal Ferns in Chandraprabha Wildlife Sanctuary, Chandauli, Uttar Pradesh
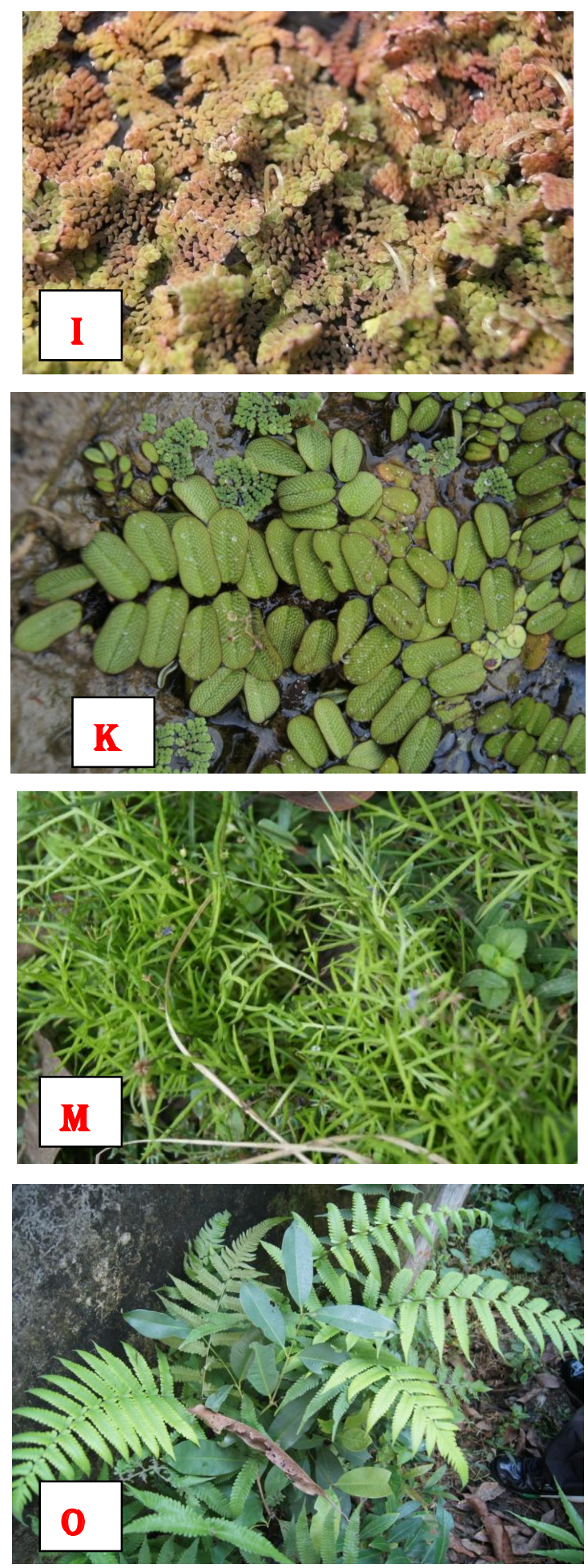
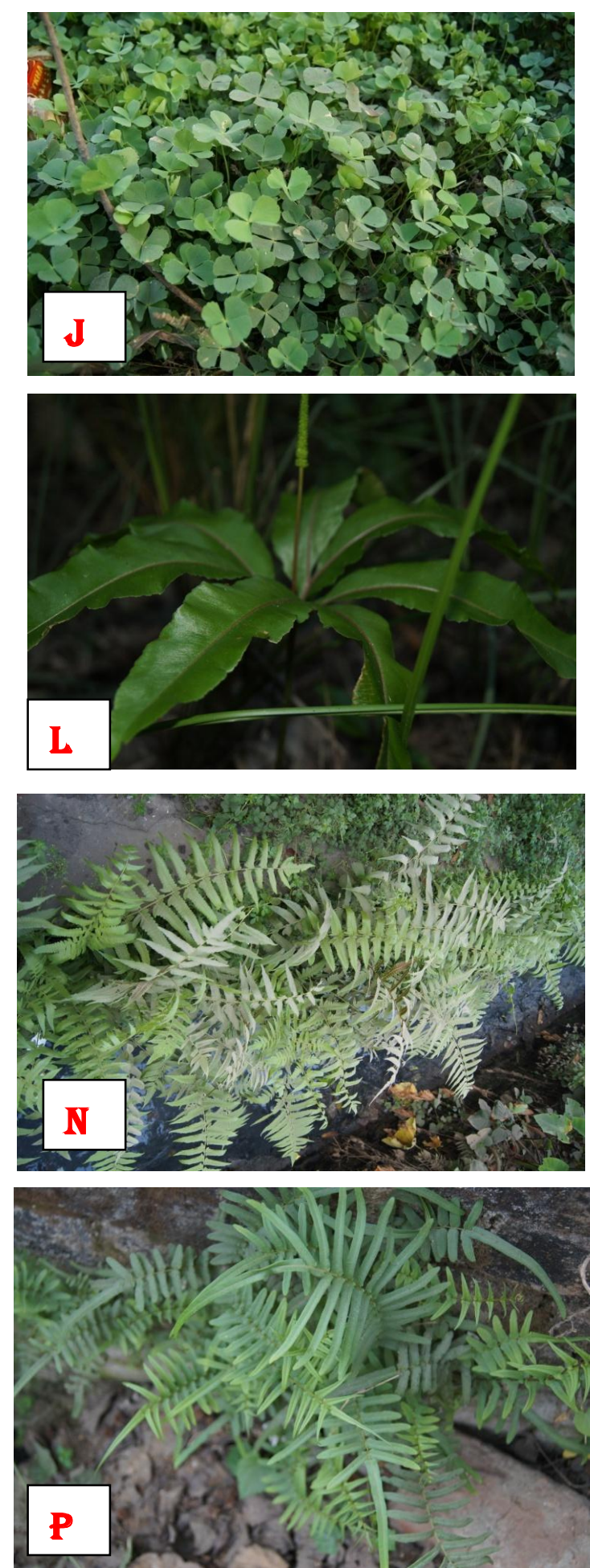

A. Adiantum philippense L. B. Adiantum incisum Forrsk. C. Adiantum capillus-veneris L. D. Cheilanthes tenuifolia Swartz. E. Cheilanthes bicolor (Roxb.in Griff.) Griff. ex Fras.-Jenk, F. Ophioglossum peteolatum Hook., G. Ophioglossum costatum R. Br. H. Selaginella bryopteris L. I. Azolla pinnata R. Br., J. Marsilea minuta L., K. Salvinia natans L., L. Helminthostachys zeylanica L. Hook.,M. Ceratopteris thalictroides (L) Brongn., N. Diplazium esculentum (Retz.) Sw.,O. Thelypteris dentata (Forssk.), P. Pteris vittata L.

\section{REFERENCES}

[1] Chandra, S. 2000, the Ferns of India (Enumeration, Synonyms and Distribution), International Book Distributors Dehra Dun.

[2] Dhiman, A.K. 1998. Ethnomedicinal uses of some pteridophytic species in India. Indian Fern J. 15: 61-64.

[3] Dixit, R.D. 1974. Ferns- a much neglected group of medicinal plants III, J. Res. Indian Med. 9(4):59-68.

International Journal of Research Studies in Biosciences (IJRSB)

Page | 24 
Biodiversity and Indigenous Use of Medicinal Ferns in Chandraprabha Wildlife Sanctuary, Chandauli, Uttar Pradesh

[4] Dixit, R.D. and Bhatt G.K. 1975. Fern A much neglected group of medicinal plants - II J. Res. Ind. Med. 10: $68-76$.

[5] Dixit, R.D. and Vohra, J.N. 1984. A dictionary of the pteridophytes of India. Botanical survey of India, Howrah.

[6] Dixit, R. D. 1984. A Census of the Indian Pteridophytes, Flora of India, Ser. 4, Botanical Survey of India, Howrah (Calcutta). India. pp- 1-177.

[7] Ghosh, S.R. et al. 2004. The Pteridophytic flora of eastern India. 207 - 209, BSI, Kolkata.

[8] Hodge, W.H. 1973. Fern food of Japan and the problem of toxicity. Amer. Fern. J. 63: 77-80.

[9] Kaushik, P. 1998. Ethnobotanical Importance of Ferns of Rajsthan: Indigenous Medicinal Plants. Today and Tomorrow Printers and Publication, New Delhi. pp. 61-66

[10] Khare, P.K. \& Kumar, S. 2007. Studies on some Pteridophytes used by the Tharu tribe of Dudhwa National Park, Lakimpur-Kheri Uttar Pradesh, India. Indian Fern Journal 24:137-147.

[11] Kirnura, K. and Nero, Y. 1965. Pharmacognostical studies on Chinese drug "Gu-sui-bu“: 1. Consideration on "gu-sui-bu" in old herbals (Pharmacognostical studies on fern drugs Xi). Syoyakugaku zasslii 19:25 31. In Biol. Abstr. 49: 86830.

[12] Manickam, V.S. and Ninan, C.A. 1984. Ecological studies on the Fern Flora of Palni Hills (S. India). Today and Tomorrow's Printers and Publishers New Delhi.

[13] Uddian Gias, M.D. and Pasha, M.K. 1998. Ferns of Bangladesh IV. Maratiaceae, Blechanceae, Stenoclaenaceae and Pekeriaceae, Chittagong Univ. J. sci. 23 (I): 119 - 128.

[14] Nayar, B. K. 1957. Medicinal Ferns of India. Bulletin, National Botanical Garden. 29: 1-36.

[15] Rout, S.D., Panda, T. \& Mishra, N. 2009. Ethnomedicinal studies on some Pteridophytes of Simplipal Biosphere Reserve, Orissa, India. Int. J. Med. Sci. 1(5):192-97.

[16] Sen, A. \& Ghosh, P.D. 2011. A note on the ethnobotanical studies of some Pteridophytes in Assam. Indian J. Trad. Knowledge 10(2):292-95.

[17] Singh, A.P. \& Khare, P.B. 2011. Status of ethno-Pteridology in India. Applied Botany abstracts 31(4):332-361.

[18] Singh, K.K., Saha, S. and Maheswari, J.K. 1989. Ethnomedicinal uses of some fern amongst of Uttar Pradesh, Indian Fern J. 6: 62-67.

Citation: S. Singh \& S. Dominic Rajkumar, "Biodiversity and Indigenous Use of Medicinal Ferns in Chandraprabha Wildlife Sanctuary, Chandauli, Uttar Pradesh", International Journal of Research Studies in Biosciences (IJRSB), vol. 5, no. 11, pp. 19-25, 2017. http://dx.doi.org/10.20431/2349-0365.0511004

Copyright: (c) 2017 Authors. This is an open-access article distributed under the terms of the Creative Commons Attribution License, which permits unrestricted use, distribution, and reproduction in any medium, provided the original author and source are credited. 